\title{
DAYA TERIMA DAN ZAT GIZI PERMEN JELI DENGAN PENAMBAHAN BUBUK DAUN KELOR (MORINGA OLEIFERA)
}

\author{
Putri Safrida Rahmawati ${ }^{1}$, Annis Catur Adi $^{2}$ \\ ${ }^{1,2}$ Departemen Gizi Kesehatan, Fakultas Kesehatan Masyarakat, Universitas Airlangga, Surabaya, Indonesia \\ Email: putrisafrida94@gmail.com
}

\begin{abstract}
ABSTRAK
Daun kelor merupakan tanaman lokal yang mengandung zat gizi yang tinggi, namun pemanfaatannya sebagai bahan pangan masih sangat rendah. Agar zat gizi yang terkandung dalam daun kelor dapat dimanfaatkan tubuh, maka perlu diolah menjadi makanan yang digemari oleh masyarakat seperti halnya permen jeli. Penelitian ini dilakukan untuk mengetahui daya terima dan nilai gizi (energi dan $\beta$-karoten) permen jeli yang diformulasikan dengan bubuk daun kelor. Dengan menggunakan rancangan acak lengkap (RAL) 6 kali pengulangan pada 4 formula yaitu 1 formula kontrol (F0) dan 3 formula modifikasi (F1, F2, F3), permen jeli diujikan pada 32 panelis tidak terlatih. Adapun perlakuan yang diberikan adalah penambahan $2 \%, 4 \%$ dan $6 \%$ bubuk daun kelor. Analisis data menggunakan analisis deskriptif dan analisis statistik dengan uji Kruskal Wallis dan Mann Whitney Test $(\alpha=0,05)$ untuk mengetahui pasangan yang berbeda. Penentuan formula terbaik permen jeli diambil dari nilai rata-rata daya terima tertinggi secara keseluruhan. Hasil penilaian daya terima menunjukkan bahwa formulasi permen jeli kelor dapat diterima secara umum (warna, aroma, tekstur, dan rasa) dengan kategori suka (3). Akan tetapi, formula permen jeli dengan penambahan bubuk daun kelor paling sedikit, yaitu Formula F1 lebih banyak disukai dari segi warna, rasa, aroma, dan tekstur. Penilaian warna, aroma, dan tekstur tidak berbeda signifikan $(p>0,05)$ sedangkan pada rasa $(p<0,05)$ yang berarti penambahan bubuk daun kelor mempengaruhi rasa pada permen jeli. Sedangkan penambahan bubuk daun kelor tidak mempengaruhi warna, aroma, dan tekstur permen jeli yang dihasilkan. Formula terbaik yang direkomendasikan yaitu F1 dengan kandungan zat gizi sebesar 205,8 kkal dan 0,178 mcg $\beta$-karoten per 100 gram permen jeli.
\end{abstract}

Kata kunci: bubuk daun kelor, daya terima, Moringa oleifera, permen jeli

\begin{abstract}
Moringa oleifera is local plant rich in nutrients, unfortunately its utilization as a foodstuff is limited. In order to maximize the absorbtion of nutrients inside moringa, it should be made as favor food enjoyed by the people such as jelly candy. This research was conducted to evaluate organoleptic properties and nutritional value (energy and $\beta$-caroten) of jelly candy formulated with Moringa leaves powder. Using Comlpetely Randomized Design with 6 times repetition in 4 formulas which are 1 controlled formula and 3 modified formulas (F1, F2, and F3), jelly candy then tested to 32 untrained panels. Treatment given in this study was by adding 2\%, 4\%, and 6\% moringa leaves powder into jelly candy formula. Data was analyzed descriptively and statistically using Kruskal Wallis and Mann Whitney test to find out the difference pair. Recommended formula was chosen by counting the highest mean score of the sensory evaluation test. The result of sensory evaluation showed that Moringa Jelly Candy was generally accepted with category "like". However, jelly candy with lowest level of Moringa leaves powder (F1) was most acceptable in terms of color, odor, texture, and flavor. Statistical analysis showed that the scores of color, odor, and texture were not significantly different $(p>0.05)$ and flavor was $(p<0.005)$ which means that by adding moringa leaves powder into jelly candy formula only influence the flavor of jelly candy. Recommended jelly candy formula is F1 with nutritional analysis showed that per $100 \mathrm{~g}$ of jelly candy contains 205,8 kcal and $0.178 \mathrm{mcg}$ of $\beta$-caroten.
\end{abstract}

Keywords: moringa leaves powder, sensory evaluation, Moringa oleifera, jelly candy

\section{PENDAHULUAN}

Di Indonesia, terdapat tanaman yang mengandung banyak manfaat bagi kesehatan masyarakat dan mengandung zat gizi yang sangat tinggi mulai dari zat gizi makro hingga zat gizi mikro. Tanaman tersebut adalah Moringa oleifera atau yang lebih sering disebut pohon kelor oleh masyarakat Indonesia. Namun, tidak banyak orang mengetahui akan manfaat-manfaat pohon kelor sehingga pemanfaatannya masih sangat rendah di masyarakat. 
Salah satu manfaat yang dapat diambil dari pohon kelor terdapat pada daunnya (Kouevi, 2013). Hasil penelitian Fuglie (2001) menyatakan bahwa daun kelor memiliki berbagai kandungan nutrisi yang bermanfaat. Kandungan yang paling diunggulkan pada tanaman ini yaitu protein, vitamin $\mathrm{A}$ ( $\beta$-karoten), dan zat besinya yang tinggi sehingga bagus untuk dikonsumsi dan dapat memenuhi kebutuhan gizi terutama pada kelompok rawan (Madukwe, et al., 2013). Tidak hanya itu, daun kelor juga mengandung berbagai macam asam amino di mana hal ini jarang sekali ditemui pada sayuran (Kasolo, 2010).

Manfaat lain yang dimiliki daun kelor yaitu mampu meningkatkan status gizi pada anak malnutrisi. Penelitian yang dilakukan oleh Srikanth, et al. (2014) menunjukkan bahwa daun kelor dapat mengatasi masalah gizi buruk di berbagai negara dengan cara menambahkannya kedalam makanan sehari-hari anak. Saat ini banyak negara-negara tropis yang memanfaatkan daun kelor untuk mengatasi masalah gizi buruk pada anak dan ibu hamil (Price, 2000).

Daun kelor dapat dikonsumsi oleh manusia, namun belum banyak masyarakat Indonesia yang mengonsumsinya dikarenakan karakteristik daun kelor memiliki bau yang khas dan tidak disukai. Di daerah pedesaan, konsumsi daun kelor hanya sebatas pada olahan sayuran berkuah seperti sayur bening dan lalapan saja (Simbolon, 2008). Menurut Zakaria, et al. (2013), daun kelor tidak banyak diolah sebagai pangan fungsional. Oleh karena itu, perlu adanya inovasi dalam mengolah daun kelor menjadi suatu produk yang dapat diterima masyarakat agar kandungan nutrisi dalam daun kelor dapat dimanfaatkan oleh tubuh.

Daun kelor dapat dibuat menjadi bubuk untuk mempermudah pemanfaatannya sebagai bahan pangan fungsional. Tidak hanya itu, daun kelor yang dikeringkan menjadi bubuk memiliki kandungan gizi yang lebih banyak daripada saat tanaman ini berbentuk daun mentah. Trees for life, yang merupakan sebuah organisasi di Amerika melaporkan bahwa per gram daun kelor kering (bubuk) mengandung 10 kali vitamin A lebih banyak dari wortel, 17 kali kalsium lebih banyak dari susu, 25 kali lebih banyak zat besi dari bayam, 9 kali lebih banyak protein dari yogurt, dan 15 kali lebih banyak potassium daripada pada pisang (Thurber \& Fahey, 2009).

Penambahan satu sendok atau lebih daun kelor kering yang telah dilumatkan (dalam bentuk serbuk) direkomendasikan oleh Church World Services (CWS) sebagai nutrisi tambahan pada makanan anak (Srikanth, et al., 2014). Banyak penelitian sebelumnya yang menggunakan formulasi tambahan daun kelor kedalam produk pangan untuk menambah nilai gizinya seperti biskuit (Kholis \& Hadi, 2010), soy meatball (Evivie, et al., 2015), yoghurt (Diantoro, et al., 2015) dan produk jelly drink (Yulianti, 2008). Dengan diolahnya daun kelor menjadi makanan kudapan yang disukai oleh semua kalangan, maka akan meningkatkan pemanfaatan daun kelor di masyarakat sehingga kandungan gizi serta manfaat lainnya yang terdapat pada daun kelor dapat diserap oleh tubuh.

Permen jeli merupakan salah satu jenis kudapan yang disukai oleh hampir semua golongan usia, terutama anak-anak. Permen jeli disukai karena rasanya yang manis dan juga teksturnya yang unik. Selain itu, permen jeli dapat diolah dengan berbagai macam variasi baik dari bahan baku, rasa, warna, dan juga bentuk yang menarik. Jenis kudapan confectionery atau gula-gula semacam permen dapat menggantikan energi yang hilang dengan cepat (Tamer, Incedayi, Copur, \& Karmea, 2013), akan tetapi permen jeli konvensional mengandung gula yang tinggi dan rendah akan nilai zat gizi seperti vitamin dan mineral.

Permen jeli yang dibuat dari buah ataupun sayuran memiliki nilai nutrisi yang lebih dibandingkan dengan yang ada di pasar yang hanya berasal dari penambahan perisa. Berdasarkan penelitian yang dilakukan oleh Hidayat dan Ikarisztiana (2004), menunjukkan bahwa permen jeli buah atau sayuran memiliki nilai nutrisi yang lebih baik. Produk permen jeli dengan rasa buah sudah banyak sekali beredar di masyarakat, akan tetapi permen jeli dari bahan dasar sayuran hijau masih jarang sekali dijumpai seperti halnya yang terbuat dari daun kelor (Moringa oleifera).

Dengan memformulasikan bubuk daun kelor ke dalam formula permen jeli akan menambah nilai gizi yang terkandung dalam permen jeli. 
Selain itu dengan adanya permen jeli kelor ini nantinya dapat meningkatkan pemanfaatan daun kelor (Moringa oleifera) sebagai suatu pangan fungsional yang mampu diterima oleh berbagai kalangan masyarakat terutama anak-anak.

Berdasarkan masalah diatas, maka perlu dilakukan kajian tentang penambahan bubuk daun kelor yang berbeda pada permen jeli yang dapat digunakan sebagai alternatif kudapan bagi anak yang diuji nilai gizi dan organoleptiknya.

\section{METODE}

Penelitian ini merupakan eskperimental murni pada tahap pengembangan formulasi permen jeli dan eksperimental semu pada tahap uji organoleptik. Desain penelitian menggunakan Rancangan Acak Lengkap (RAL) dengan 4 perlakuan dan 6 kali pengulangan. Perlakuan merupakan penambahan bubuk daun kelor yang berbeda pada formula permen jeli yaitu F0, F1, F2, F3, dan F4. Penelitian dilakukan sebanyak dua kali yaitu penelitian pendahuluan dan penelitian lanjutan. Penelitian pendahuluan pada panelis terbatas bertujuan untuk mengambil tiga formula modifikasi terbaik untuk diujikan secara organoleptik pada 32 orang panelis tidak terlatih. Formula terbaik yang diujikan secara organoleptik pada penelitian lanjutan yaitu satu formula kontrol (0\%), F1 (2\%), F2 (4\%), dan F3 (6\%). Penelitian ini telah mendapatkan persetujuan dari komisi penguji etik sebelum dilakukan uji organoleptik pada panelis. Data dianalisis secara statistik menggunakan uji non-parametrik Kruskal Wallis dan jika terdapat perbedaan signifikan maka untuk mengetahui pasangan yang berbeda menggunakan uji Mann Whitney dengan $\alpha=0,05$. Penentuan formula terbaik diambil dari nilai rata-rata tertinggi dari keseluruhan daya terima permen jeli.

Peralatan yang digunakan pada penelitian ini adalah pengaduk kayu, cetakan silikon permen, gelas, non-sticky pot, termometer permen, dan seperangkat alat uji organoleptik. Semua peralatan yang digunakan sama untuk semua perlakuan. Dalam penelitian ini, bubuk daun kelor didapatkan dari PT. Moringa Organik Indonesia yang ditanam di Kabupaten Blora-Jawa Tengah. Bahan permen jeli yang digunakan dalam penelitian ini meliputi
Tabel 1. Formulasi Permen jeli kelor

\begin{tabular}{lcccc}
\hline \multirow{2}{*}{ Formula Bahan $(\mathbf{g})$} & F0 & F1 & F2 & F3 \\
\cline { 2 - 5 } & $\mathbf{g}$ & $\mathbf{g}$ & $\mathbf{g}$ & $\mathbf{g}$ \\
\hline Gelatin & 10 & 10 & 10 & 10 \\
Gula & 50 & 50 & 50 & 50 \\
Glukosa sirup & 25 & 25 & 25 & 25 \\
Air & 40 & 40 & 40 & 40 \\
Asam Sitrat & 1 & 1 & 1 & 1 \\
Essence & 0,5 & 0,5 & 0,5 & 0,5 \\
Pewarna makanan & 0,3 & 0,3 & 0,3 & 0,3 \\
Na. benzoat & 0,1 & 0,1 & 0,1 & 0,1 \\
Bubuk Kelor & 0 & 2 & 4 & 8 \\
Total & 125 & 127 & 129 & 133 \\
\hline
\end{tabular}

gula sukrosa yang diperoleh dari PT. Sugar Group Companies. Sedangkan bahan lainnya yaitu sirup glukosa, gelatin, asam sitrat, dan pewarna makanan, perisa buah, dan tepung tapioka. Untuk formulasi permen jeli disajikan pada tabel 1 .

\section{Pembuatan Permen Jeli}

Bubuk daun kelor dilarutkan kedalam air dengan proporsi bubuk kelor:air adalah 1:5. Selanjutnya permen jeli dibuat dengan cara mendidihkan campuran air, gula, dan glukosa sirup hingga mencapai suhu $80-90^{\circ} \mathrm{C}$. Kemudian campuran bubuk daun kelor yang telah dilarutkan dimasukkan dan diaduk secara merata hingga mencapai suhu $100-110^{\circ} \mathrm{C}$. Setelah itu gelatin yang telah dilarutkan dengan air $\left(70^{\circ} \mathrm{C}\right)$ ditambahkan kedalam larutan permen jeli dan diaduk perlahan. Pada saat suhu turun mencapai $90^{\circ} \mathrm{C}$ asam sitrat dimasukkan kemudian ditambahkan essens dan pewarna secukupnya agar warna permen yang dihasilkan lebih menarik. Permen jeli yang telah dituang kedalam cetakan disimpan pada suhu ruangan $\left(27^{\circ} \mathrm{C}\right)$ dengan ditutup menggunakan aluminium foil selama 24 jam. Terakhir permen tersebut dikeluarkan dari cetakan dan dilapisi dengan tepung tapioka dan tepung gula yang telah disangrai terlebih dahulu dengan perbandingan $1: 1$.

\section{Uji Organoleptik}

Pengujian organoleptik dilakukan dengan tujuan untuk menilai karakteristik warna, aroma, tekstur (kekenyalan), dan rasa permen jeli. 
Empat sampel permen jeli diberi kode berupa angka $(901,112,234$, dan 351) dan disajikan secara acak kepada 32 panelis tidak terlatih yang merupakan siswa-siswi SD kelas 4. Air mineral diberikan kepada panelis di antara penilaian tiap sampel permen dengan tujuan untuk menetralkan indera pengecap. Skala penilaian uji organoleptik menggunakan 4 kategori dengan nilai yaitu 1 = sangat tidak suka, $2=$ tidak suka, $3=$ suka, dan $4=$ sangat suka.

\section{Analisa Zat Gizi}

Keempat formula permen jeli dianalisis menggunakan tabel Daftar Komposisi Bahan Makanan (DKBM) Depkes RI (2014) untuk diketahui jumlah energi dan kandungan vitamin A (beta-karoten). Analisa laboratorium dilakukan pada 1 formula terbaik yang terpilih berdasarkan penilaian tertinggi pada uji organoleptik. Untuk melihat kandungan vitamin A (beta-karoten) menggunakan metode GC (Gas Chromatograf).

\section{HASIL DAN PEMBAHASAN}

Uji organoleptik dilakukan untuk mengetahui apakah produk permen jeli kelor dapat diterima oleh konsumen. Hasil uji organoleptik dapat menunjukkan formula mana yang paling disukai oleh panelis sehingga dari keempat formula permen dapat dipilih satu produk terbaik berdasarkan penilaian daya terimanya. Nilai rata-rata kesukaan panelis yang meliputi penilaian warna, aroma, tekstur (kekenyalan), dan rasa dapat dilihat pada tabel 2.

Penilaian organoleptik permen jeli secara umum menunjukkan rata-rata panelis memberikan penilaian suka hingga sangat suka pada keempat formula permen jeli. Hal ini menunjukkan formula permen jeli masih dapat diterima oleh masyarakat terutama untuk formula $\mathrm{F} 1$ yang mempunyai nilai rata-rata tinggi daripada formula modifikasi lainnya. Namun demikian, penerimaan formula kontrol (F0) masih lebih disukai oleh panelis.

Dari hasil penilaian organoleptik dapat dikatakan bahwa adanya penambahan bubuk daun kelor pada formula permen jeli memberikan penerimaan sensori yang berbeda pada konsumen.
Dengan ditambahkannya bubuk daun kelor pada permen jeli, maka penerimaan produk menjadi menurun. Hal ini sejalan dengan penelitian yang dilakukan oleh Otunola, et al. (2013) pada pembuatan cookies dengan moringa leave waste, bahwa dengan ditambahkannya moringa leave waste maka daya terima produk menurun.

\section{Warna}

Penilaian organoleptik terhadap warna permen jeli kelor menunjukkan bahwa warna sangat mempengaruhi penerimaan permen jeli. Hasil penilaian organoleptik pada tabel 2 dapat diketahui bahwa penilaian tertinggi pada karakteristik warna terdapat pada formula F0. Rata-rata penilaian kesukaan terhadap warna berada pada skala 3,25-3,59 yang termasuk dalam kategori sukasangat suka. Permen jeli kelor memiliki warna hijau tua yang gelap, berbeda dengan permen jeli kontrol (F0) yang memiliki warna hijau bening. Seiring ditambahkannya bubuk daun kelor maka warna hijau yang dihasilkan menjadi semakin gelap dan kurang menarik. Hal ini membuat penurunan penerimaan permen pada panelis karena menurut Winarno (2006), warna merupakan rangsangan pertama pada indera mata yang mempengaruhi penerimaan makanan.

Warna permen jeli pada formula F0 merupakan warna permen jeli yang paling disukai oleh panelis. Panelis cenderung menyukai warna formula F0 dikarenakan warna yang dihasilkan lebih menarik apabila dibandingkan dengan formula modifikasi (F1, F2, F3). Hasil uji Kruskal Wallis menunjukkan bahwa penambahan bubuk daun kelor tidak berpengaruh $(\mathrm{p}=0,16)$ terhadap warna permen jeli kelor. Hal ini berarti bahwa warna permen jeli F1 tidak berbeda nyata dengan warna permen jeli F2 dan F3.

\section{Aroma}

Aroma suatu makanan menentukan kelezatan makanan tersebut. Suatu produk pangan akan lebih mudah diterima oleh konsumen jika memiliki aroma yang khas dan menarik (Winarno, 2006).

Penilaian organoleptik terhadap aroma permen jeli menunjukkan bahwa dari segi aroma, permen jeli kelor masih dapat diterima oleh konsumen 
Tabel 2. Hasil Penilaian Uji Organoleptik Permen Jeli

\begin{tabular}{|c|c|c|c|c|c|c|c|c|c|c|c|c|}
\hline \multirow{3}{*}{\multicolumn{2}{|c|}{ Formula }} & \multicolumn{8}{|c|}{ Penilaian } & \multirow{2}{*}{\multicolumn{2}{|c|}{ Total }} & \multirow{3}{*}{ Rata-rata } \\
\hline & & \multicolumn{2}{|c|}{1} & \multicolumn{2}{|c|}{2} & \multicolumn{2}{|c|}{3} & \multicolumn{2}{|c|}{4} & & & \\
\hline & & $\mathbf{n}$ & $\%$ & $\mathbf{n}$ & $\%$ & $\mathbf{n}$ & $\%$ & $\mathbf{n}$ & $\%$ & $\mathbf{N}$ & $\%$ & \\
\hline \multirow{4}{*}{ Warna } & F0 & 0 & 0 & 1 & 3,13 & 2 & 6,25 & 29 & 90,63 & 32 & 100 & 3,88 \\
\hline & $\mathrm{F} 1$ & 0 & 0 & 4 & 12,50 & 17 & 53,13 & 11 & 34,38 & 32 & 100 & 3,21 \\
\hline & F2 & 4 & 12,50 & 6 & 18,75 & 9 & 28,13 & 13 & 40,63 & 32 & 100 & 2,97 \\
\hline & F3 & 7 & 21,87 & 6 & 18,75 & 10 & 31,25 & 9 & 28,13 & 32 & 100 & 2,66 \\
\hline \multirow{4}{*}{ Aroma } & F0 & 1 & 3,13 & 1 & 3,13 & 8 & 25,00 & 22 & 68,75 & 32 & 100 & 3,59 \\
\hline & F1 & 0 & 0 & 2 & 6,25 & 18 & 56,25 & 12 & 37,50 & 32 & 100 & 3,31 \\
\hline & F2 & 0 & 0 & 9 & 28,13 & 11 & 34,37 & 12 & 37,50 & 32 & 100 & 3,09 \\
\hline & F3 & 0 & 0 & 9 & 28,13 & 6 & 18,75 & 17 & 53,12 & 32 & 100 & 3,25 \\
\hline \multirow{4}{*}{ Tekstur } & F0 & 0 & 0 & 1 & 3,13 & 8 & 25,00 & 23 & 71,88 & 32 & 100 & 3,68 \\
\hline & $\mathrm{F} 1$ & 0 & 0 & 2 & 6,25 & 10 & 31,25 & 20 & 62,50 & 32 & 100 & 3,56 \\
\hline & $\mathrm{F} 2$ & 0 & 0 & 3 & 9,38 & 10 & 31,25 & 19 & 59,38 & 32 & 100 & 3,50 \\
\hline & F3 & 0 & 0 & 5 & 15,6 & 9 & 28,13 & 18 & 56,25 & 32 & 100 & 3,40 \\
\hline \multirow{4}{*}{ Rasa } & Fo & 1 & 3,1 & 0 & 0 & 0 & 0 & 31 & 96,88 & 32 & 100 & 3,94 \\
\hline & $\mathrm{F} 1$ & 0 & 0 & 1 & 3,13 & 13 & 40,63 & 18 & 56,25 & 32 & 100 & 3,53 \\
\hline & F2 & 4 & 12,50 & 8 & 25,00 & 7 & 21,88 & 13 & 40,63 & 32 & 100 & 2,90 \\
\hline & F3 & 2 & 6,25 & 13 & 40,63 & 9 & 28,13 & 8 & 25,00 & 32 & 100 & 2,72 \\
\hline
\end{tabular}

dengan skala penilaian 3,40-3,68. Aroma dari formula F1 menjadi yang paling disukai oleh panelis, sedangkan aroma pada formula permen jeli F2 memiliki penerimaan yang rendah dibandingkan dengan formula F1 dan F3. Akan tetapi, hasil uji Kruskal Wallis menunjukkan nilai signifikansi $\mathrm{p}=0,561$ sehingga dapat dikatakan bahwa penambahan bubuk daun kelor tidak berpengaruh nyata terhadap aroma permen jeli kelor. Namun demikian, apabila dibandingkan dengan formula permen jeli kontrol (F0), aroma permen jeli tanpa bubuk daun kelor lebih disukai oleh panelis.

Pada formulasi permen jeli diberikan perisa lemon dengan tujuan untuk menutupi aroma langu dari daun kelor yang mampu mempengaruhi daya terima produk. Hal ini sejalan dengan penelitian Yulianti (2008) bahwa pemberian perisa dalam produk minuman jeli kelor sangat penting dalam mempengaruhi tanggapan organoleptik dan penerimaan konsumen terhadap produk. Kesukaan yang tinggi terhadap aroma permen jeli pada formula kontrol (F0) dapat disebabkan karena tidak adanya percampuran aroma bubuk daun kelor (Moringa oleifera) dalam formula permen. Aroma yang dihasilkan oleh F0 lebih terasa kuat pada aroma masam perisa lemon dibandingkan dengan formula modifikasi. Hal ini disebabkan karena adanya penambahan bubuk daun kelor pada formula modifikasi (F1, F2, dan F3).

\section{Tekstur}

Penilaian kesukaan tertinggi pada karakteristik tekstur (kekenyalan) terdapat pada formula F0. Rata-rata penilaian kesukaan terhadap tekstur berada pada skala 2,6-3,8 yang termasuk dalam kategori suka-sangat suka.

Tekstur produk permen jeli kelor dinilai dari sifat kekenyalan yang dapat dirasakan oleh panelis dengan indera peraba dan pengecap. Penilaian organoleptik terhadap tekstur permen jeli kelor menunjukkan bahwa dari segi tekstur permen jeli kelor masih dapat diterima oleh masyarakat. Tekstur permen jeli kelor yang paling disukai oleh panelis adalah tekstur pada formula permen F1. Formula permen jeli F1 memiliki penerimaan hampir sama dengan formula permen jeli kontrol (F0). Daya terima tekstur antara permen jeli F1, F2, dan F3 tidak menunjukkan perbedaan yang signifikan. Apabila dibandingkan dengan formula kontrol, tekstur permen jeli tanpa daun kelor masih lebih disukai oleh panelis. Namun demikian, hasil uji Kruskal Wallis tidak menunjukkan adanya perbedaan signifikan $(p=0,758)$, sehingga dapat dikatakan bahwa penambahan bubuk daun kelor tidak mempengaruhi tekstur permen jeli.

Permen jeli gelatin memiliki konsistensi yang lunak dan bersifat seperti karet (Koswara, 2009). Formula kontrol (F0) lebih disukai karena tekstur 
yang dihasilkan pada formula ini lebih kenyal dan tidak terlalu lunak. Sedangkan tekstur formula F3 memiliki nilai rendah dari panelis dikarenakan tekstur yang dihasilkan lebih lunak dan kurang kenyal. Hal ini diakibatkan karena banyaknya bubuk daun kelor yang ditambahkan kedalam formulasi. Setiap penambahan bubuk daun kelor kedalam adonan permen jeli, maka bubuk daun kelor harus dilarutkan terlebih dahulu dengan air 1:5 dari berat $(\mathrm{g})$ bubuk kelor sehingga semakin banyak bubuk daun kelor yang ditambahkan, maka kandungan air dalam formula permen jeli semakin banyak. Hal ini berpengaruh terhadap pembentukan gel. Tekstur gel yang dihasilkan permen jeli dipengaruhi oleh konsentrasi gelatin yang digunakan dalam formula. Menurut Koswara (2009), jumlah gelatin yang diperlukan untuk menghasilkan gel yang memuaskan berkisar antara 5-12\%, dan kadar air yang rendah dapat menurunkan plastisitas permen yang menghasilkan sifat lebih keras pada permen jeli, begitu pula sebaliknya.

\section{Rasa}

Hasil uji organoleptik menunjukkan bahwa permen jeli kelor masih dapat diterima oleh masyarakat meskipun sebagian permen tidak begitu disukai oleh panelis. Penilaian kesukaan tertinggi pada karakteristik rasa terdapat pada formula F0. Rata-rata penilaian kesukaan terhadap rasa berada pada skala 2,72-3,94 (suka-sangat suka).

Permen jeli kelor yang paling disukai oleh panelis adalah permen jeli formula F1, sedangkan permen jeli formula F3 tidak terlalu disukai. Namun demikian, apabila dibandingkan dengan formula kontrol (F0), permen jeli tanpa penambahan bubuk daun kelor lebih disukai oleh panelis. Hal ini sejalan dengan penelitian yang dilakukan oleh Otunola, et al. (2013), di mana cookies tanpa moringa leave waste lebih disukai rasanya dibandingkan dengan cookies yang disubtitusi dengan moringa leave waste.

Tingkat kesukaan yang tinggi terhadap formula permen jeli $\mathrm{F} 1$ oleh panelis dapat disebabkan karena sedikitnya bubuk daun kelor (2\%) yang terkandung dalam formula permen jeli sehingga aroma dan rasa langu dari daun kelor masih dapat tertutupi oleh rasa asam dan aroma dari sitrat dan perisa. Sebaliknya, dengan tingkat kesukaan yang rendah pada formula permen jeli F3 oleh panelis dapat disebabkan karena semakin banyak bubuk daun kelor yang ditambahkan $(6 \%)$ maka rasa dan aroma daun kelor terasa lebih kuat dan tidak tertutupi oleh asam sitrat dan perisa.

Nilai rata-rata daya terima permen jeli kelor semakin menurun seiring ditambahkannya bubuk daun kelor pada formula. Sejalan dengan penelitian Evivie, et al. (2015) yang menyatakan bahwa penambahan kadar bubuk daun kelor yang berbeda mempengaruhi daya terima rasa produk.

Hasil uji Kruskal Wallis menunjukkan bahwa penambahan bubuk daun kelor berpengaruh nyata $(\mathrm{p}=0,001)$ terhadap rasa permen jeli kelor. Uji lanjut Mann Whitney menunjukkan bahwa terdapat 2 pasangan formula yang berbeda yaitu pada pasangan formula $\mathrm{F} 1$ dan $\mathrm{F} 2(\mathrm{p}=0,023)$ dan formula F1 dan F3 $(p=0,000)$. Sedangkan pada pasangan formula F2 dan F3 tidak berbeda secara signifikan $(p=0,217)$.

\section{Nilai Gizi}

Permen jeli dianalisis zat gizinya dengan perhitungan secara empiris menggunakan tabel DKBM dan analisis laboratorium hanya pada formula yang paling disukai oleh panelis yaitu formula F1. Hasil analisis empiris ditampilkan dalam tabel 3 .

Permen jeli merupakan makanan jenis kudapan. Menurut Syafitri (2009), makanan kudapan menyumbangkan $10-15 \%$ terhadap kebutuhan energi sehari. Berdasarkan analisis empiris zat gizi menggunakan DKBM, per 100 gram permen jeli mampu memberikan energi 246-250 kkal dan beta-karoten 0,2-0,9 mcg. Untuk mencukupi $10-15 \%$ kebutuhan vitamin A (beta-karoten) untuk anak-anak yaitu $0,05 \mathrm{mcg}$, maka takaran saji yang direkomendasikan sebanyak 25 gram atau \pm 5 buah permen.

Tabel 3. Analisa Nilai Gizi Formula Permen Jeli (DKBM) untuk $100 \mathrm{~g}$

\begin{tabular}{lcccc}
\hline \multicolumn{1}{c}{ Kandungan } & F0 & F1 & F2 & F3 \\
\hline Energi (kkal/100 g) & 249,5 & 249 & 248,2 & 246,8 \\
Vit.A ( $\beta$-karoten) & 0 & 0,2 & 0,5 & 0,9 \\
(mcg) & & &
\end{tabular}

Sumber: DKBM (2014) 
Tabel 4. Hasil Analisa Nilai Gizi Formula F1 (Laboratorium) untuk $100 \mathrm{~g}$

\begin{tabular}{lc}
\hline \multicolumn{1}{c}{ Kandungan Gizi } & Formula F1 \\
\hline Energi (kkal) & 205,8 \\
Beta-karoten (mcg) & 0,178 \\
\hline
\end{tabular}

Hasil analisa laboratorium dilakukan pada formula yang paling disukai panelis yaitu formula F1 yang ditunjukkan pada tabel 4. Apabila hasil analisis nilai gizi laboratorium dibandingkan dengan analisa DKBM terdapat penurunan sedikit kandungan pada kadar beta-karoten yang dapat diakibatkan karena proses pemasakan dengan panas. Menurut U.S Departement of Agriculture, sayuran kehilangan 10-15\% total beta-karoten melalui proses perebusan (Imsic, 2010). Akan tetapi, dengan proses pemanasan mampu meningkatkan bioavaibilitas beta -karoten (Rock, et al., 1998)

\section{Formula Terbaik}

Pemilihan formula terbaik permen dilihat dari rata-rata daya terima secara keseluruhan dari segi warna, aroma, tekstur dan rasa. Hasil uji organoleptik pada tabel 2 menunjukkan bahwa formula $\mathrm{F} 1$ memiliki penerimaan paling tinggi dibandingkan dengan formula F2 dan F3 sehingga formula permen jeli yang direkomendasikan adalah formula $\mathrm{F} 1$.

\section{KESIMPULAN DAN SARAN}

Hasil penilaian organoleptik permen jeli kelor masih dapat diterima oleh masyarakat dengan formula yang paling disukai yaitu formula F1 ( $2 \%$ bubuk daun kelor). Tidak ada perbedaan signifikan antara daya terima permen jeli F1 dan F0 sehingga formula F1 dapat direkomendasikan sebagai kudapan bagi anak-anak dengan kandungan gizi yang lebih banyak daripada permen jeli konvensional. Per 100 gram permen jeli kelor F1 mampu menyumbangkan energi sebesar 205,8 kkal dan mengandung beta -karoten sebesar $0,178 \mathrm{mcg}$. Namun demikian, perlu adanya pengembangan lebih lanjut terhadap formulasi agar dapat meningkatkan daya terima warna, rasa, dan aroma permen jeli kelor. Penelitian lebih lanjut mengenai kandungan gizi juga perlu dilakukan untuk mengetahui seberapa besar zat gizi lainnya yang ada pada permen jeli kelor

\section{DAFTAR PUSTAKA}

Departemen Kesehatan RI. (2014). DKBM (Daftar Komposisi Bahan Makanan). Jakarta: Departemen Kesehatan RI.

Diantoro, A., Rohman, M., Budiarti, R., \& Palupi, H. T. (2015). Pengaruh Penambahan Ekstrak Daun Kelor (Moringa oleiera L.) Terhadap Kualitas Yoghurt. Jurnal Teknologi Pangan, 6(2), no. 1: 59-66. Diakses dari http:// jurnal.yudharta.ac.id/category/jurnal-teknologipangan/

Evivie, S., Ebabhamiegebho, P., Imaren, J., \& Igene, J. (2015). Evaluating The Organoleptic Properties of Soy Meatballs (BEEF) with Varying Level of Moringa Oleifera Leaves Powder. Journal Application Science Environment Management (JASEM), 649-656. Diakses dari www.bioline. $\mathrm{org} / \mathrm{br} / \mathrm{ja}$

Fuglie, L. (2001). Combating Malnutrition With Moringa. Development potential for Moringa products, 1(1), 1-4.

Hidayat, N., \& Ikarisztiana, K. (2004). Membuat Permen Jelly. Surabaya: Trubus Agrisarana.

Imsic, M.W. (2010). Effect of Storage and Cooking on Beta-Caroten Isomers in Carrots (Daucus carota L. cv.'Stefano). J Agric Food Chem, 58(8), 5109-13. doi:10.1021/jf904279j

Kasolo, J.N. (2010). Phytochemicals and Uses of Moringa Oleifera Leaves in Ugandan Rural Communities. Academic Journals, 4(9), 753-757. Diakses dari www.academicjournals. org

Kouevi, K.K. (2013). A Study on Moringa oleifera leaves as a supplement to West African Weaning Foods, Hamburg: University of Aplied Science.

Kholis, N., \& Hadi, F. (2010). Pengujian Bioassay Biskuit Balita Yang Disuplementasi Konsentrat Protein Daun Kelor (Moringa Oleifera) Pada Model Tikus Malnutrisi. Jurnal Teknologi Pertanian, 11(3), 144-151. Diakses dari http:// jtp.ub.ac.id

Koswara, S. (2009). Teknologi Pembuatan Permen. Diakses dari http://tekpan.unimus. ac.id/wpcontent/uploads/2013/07/teknologipembuatan-permen.pdf 
Madukwe, E., Ugwuoke, A. \& Ezeugwu, J. (2013). Effectiveness Of Dry Moringa Oleifera Leave Powder In Treatment Of Anemia. Academic Journals, 5(5), 226-228. Diakses dari www. academicjournals.org/

Otunola, G., Arise, A., Sola Ojo, F., Nmom, I., \& Troye, A. (2013). The Effect Of Addition of Moringa Leave Waste Fibre on Proximate and Sensory Characteristics of Cookies. Agrosearch, 13(1), 69-75. Diakses dari http://www.echonet. org/

Price, M.L. (2007). The Moringa Tree. Durrance Road, North Forth Myers, USA: ECHO. Diakses dari www.echonet.org: http://www. echonet.org/

Rock, C.L., Lovalvo, J.L., Emenhiser, C., \& Ruffin, M.T. (1998). Bioavailability of Beta-Caroten is Lower in Raw than in Processed Carrots And Spinach in Women. Journal nutrition, 128(5), 913-6. Diakses dari http://www.ncbi.nlm.nih. gov/pubmed/9567003

Simbolon, J.M., Sitorus, M., \& Nelly, K. (2008). Cegah Malnutrisi dengan Kelor. Yogyakarta: Kanisius.

Srikanth, V.S., Mangala, S. \& Subrahmanyam, G., (2014). Improvement of Protein Energy Malnutrition by Nutritional Intervention with Moringa Oleifera Among Anganwadi Children in Rural Area in Bangalore, India. International Journal of Scientific Study, 2(1), 32-35. Diakses dari www.ijss-sn.com/uploads/2/0/1/.../ijss_apr08.pdf
Syafitri, Y., Syarief, H. \& Baliwati, Y.F., (2009). Kebiasaan Jajan Siswa Sekolah Dasar (studi kasus di SDN Lawang gintung 01 Kota Bogor). Jurnal Gizi dan Pangan, 4(3), 167-175. Diakses dari journal.ipb.ac.id/index.php/jgizipangan/ article/viewFile/7680/5949

Tamer, C.E., Incedayi, B., Copur, O.U., \& Karmea, M. (2013). A Research $n$ The Fortification Application for Jelly Confectionery. Journal of Food, Agriculture, and Environmental, 11(2), 152-157. Diakses dari www.world-food.net/aresearch-on-the-fortification-application-forjelly-confectionery/

Thurber, M.D. \& Fahey, J.W., (2009). Adoption of Moringa Oleifera to Combat Undernutrition Viewed Through The Lens of the "Diffussion of Innovations" Theory. Ecol Food Nutr, 48(3), 212-225. Diakses dari www.ncbi.nlm.nih.gov/ pubmed/20161339

Winarno, F.G. (2006). Kimia Pangan dan Gizi. Jakarta: PT Gramedia Pustaka Utama.

Yulianti, R. (2008). Pembuatan Minuman Jeli Daun Kelor (Moringa oleifera lam) sebagai Sumber Vitamin C dan Beta Karoten. (Skripsi yang tidak dipublikasikan). IPB, Bogor.

Zakaria, Thamrin, A., Lestari, R.S., \& Hartono, R. (2013). Pemanfaatan Tepung Kelor (Moringa oleifera) dalam Formulasi Pembuatan Makanan Tambahan untuk Balita Gizi Kurang. Media Gizi Pangan, Vol. XV, edisi no. 1. Diakses dari https://jurnalmediagizipangan.files.wordpress. com 